\title{
Post mortem body donation and notes on the history of dissection
}

\author{
B Fedi $^{1}$

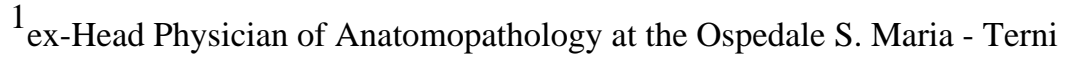

submitted: Oct 6, 2020, accepted: Nov 27, 2020, EPub Ahead of Print: Dec 21, 2020

Conflict of interest: None

DOI: 10.24019/jtavr.90 - Corresponding author:Prof. Bruno Fedi, brunofedi2@ gmail.com

(C) 2020 Fondazione Vasculab impresa sociale ONLUS. All rights reserved.

\begin{abstract}
The author provides a very short history of the learning of medical and surgical knowledge, stressing the importance of studies on man undertaken by the Egyptians, of the Viennese school at the end of the 1800s, and looking at how things are today. The role of anatomical pathology is emphasised along with its importance in the contemporary age thanks to microsurgery, degenerative diseases of the CNS, the Corona Virus pandemic etc. The Project for Body Donation, recently approved by the Italian parliament, is also illustrated.
\end{abstract}

Abstract L'autore fornisce una brevissima storia dell'apprendimento di conoscenze medico-chirurgiche, sottolineando l'importanza degli studi condotti sull'uomo dagli egizi, alla scuola viennese di fine 1800, fino ad oggi. Viene enfatizzato il ruolo dell' anatomia patologica e la sua importanza nell'era contemporanea per la microchirurgia, le malattie degenerative del SNC, la pandemia da Corona Virus, ecc. Viene anche illustrato il Progetto di Donazione Dei Corpi recentemente approvato dal Parlamento Italiano.

Keywords Post Mortem Donation, Surgical Dissection History, Degenerative neurological diseases, Microsurgery in corpses, Rare diseases

The history of medicine, initially confused with religious or magical practices, clearly shows how difficult it has been to arrive at the current spectacular scientific progress, when starting from superstitions, prejudices, and absurdities of every type. To me it appears obvious to stress the fact that an enormous amount of species-specific research work was necessary, starting with the structure itself, that is, the anatomy. One may know how man is made, how man works and how man gets ill, only by studying man.

One of the very first surgeons we know by name is the Egyptian Imhotep. Certainly, he was one of the first to know human anatomy and pathology.

In Europe, the Greeks had understood the importance of man, even though in a way totally indifferent any ethical consideration. In the third century BC, Herophilos discovered a "Torcula" cutting the cranium of a living slave. Erasistratus, again directly on man, distinguished venous and arterial circulation. Galen, unlike Herophilos and Erasistratus, carried out experiments on animals, even though he did not believe they were as reliable as those on man. However, he described the functioning of the organs and the anatomy.

With the success of Christianity and the barbaric invasions, research on cadavers ceased and there was also an arrest in medical progress. Ideas dating back to Hippocrates (Doctrine of the humours) were believed wellfounded, their being, in reality, a first attempt to give a non-magical or superstitious explanation of illnesses. Some methods were practiced even when detrimental.

The return of scientific progress once again started with research on man, that was sometimes carried out under grave danger for the researchers themselves, because they could be accused of witchcraft. Later, this would no longer occur.

Therefore, even in the Middle Ages, progress, did not stop totally. From the 12th century the study of anatomy on man returned. Fracastoro discovered "contagion"; the first hospitals emerged. Research on cadavers was never 
completely abandoned, but medical studies were still associated to other subjects: degrees are given in Medicine and Philosophy.

However, medicine and surgery proceeded separately: the great number of the battle wounds favoured surgery. Slowly, the concept of study on man made ground; by dissecting cadavers Vesalio changed anatomy, which still relied on the studies of Galen, but progress in other disciplines are also important for progress of medicine.

A very important turning point came with the first microscopes and the anatomic, histological and anatomical pathology research of Malpighi and of Harvey. However, in 1602, plague broke out in Milan and ignorance was again sovereign. Scientific knowledge was limited to a handful of people.

The real epoch making transformation, the jump to modernity, happened in the 19th century with Virchow. This anatomopathologist is certainly one of the fathers of modern medicine. (Here it is not possible to mention all of them, but Kock and Pasteur cannot be passed over in silence and it would be ingenious not to mention Semmelweis). Virchow represents a fundamental change because he systematically relates the macro- and microscopic alterations found in the autoptic examination to the symptomology found before death. He does not do this only in a few cases, he dos it for all cases, systematically. So, he does not explain a case, but rather, identifies a method that allows explanation of the symptoms of pneumonia, through "the hepatization of the pulmonary tissue"; he allows creating a relationship between hepatic cirrhosis and jaundice and ascites etc, etc.

Virchow is not alone: the discovery of the "Micobacterium Tubercolosis", cultivated in the anterior chamber of the ox eye, is also a discovery of method, and the same can be said for Pasteur's research.

With the use of cadavers for research no longer prohibited and a new ethics, one unthinkable in the Hellenist and Roman times, having now been confirmed, the bodies of the unclaimed dead, became a means of study. They served in all fields: anatomic knowledge, experimenting the concrete feasibility of surgical interventions made possible by anaesthetics and antibiotics; practice for future surgeons; or study and practice for students.

Surgery, practiced in Antiquity, but concretely limited to the treatment of wounds, of distortions, dislocations, fractures, and not much else, undergoes stunning development.

Descriptions of the first operations for gastrectomy, cystectomy and even simple mastectomy, today an elementary operation, are dramatic. Besides, these operations were carried out without, or with approximate, preparation. The first reports of attempted interventions date back a time before antibiotics and before anaesthetics. A lot of knowledge comes thanks to experience on cadavers. As an example one may consider the prostatic adenomectomy, via subpubic, that would not have been possible to learn by experimenting on dogs because of the greater height of the pubis. The first successful operation on the prostate, in fact, happened per via perineum, in the $16^{\text {th }}$ century. We do not know if, as is probable, it led to incontinence and impotency.

As the student of a famous surgeon, having seen many others operate, I can say that not a few operations, or variants, were conceived directly on an ill patient. Other times there was lengthy preparation on cadavers. Once again, though, ethics were not respected: the cadavers in the study were those not reclaimed by anyone: i.e. the bodies of the poor, which is immoral. But we have come to a time when society and research evolve rapidly. Study courses change. Disciplines that were at first monolithic have become fragmented; other disciplines hide or take on importance. There is a need for new knowledge in previously inexistent fields (anaesthesia, microbiology, statistics, etc.).

Medical studies require less direct experience on human bodies, while contemporaneously the need for research in new sectors increases: transplants, microsurgery, endoscopic surgery, etc. Clearly Virchow's teachings are still current.

However, new illnesses have appeared, while others have become less frequent, or have taken on different characteristics.

\section{Modern times}

The Corona virus pandemic is a clamorous example of the importance of anatomopathological research.

In China research was carried out (January and February 2020: 3 autopsies). Then from 22nd March 2020, in the Giovanni XXIII Hospital at Bergamo (Carsana L. et al. ${ }^{1}$ and in the Luigi Sacco Hospital in Milan (38 autopsies). These investigations report a fundamental fact for the understanding, the therapy and the prognosis. In fact, they found the first samples with widespread thromboembolisms and with widespread alveolar damage. The autopsies were carried out despite the recommendation of the Ministry which provided very restricted instructions on their execution. "The position of the Ministry is expressed in the report ISS Covid-19 n.6 of 23/3/2020 (New version 26/3/2020) ${ }^{2}$ and, then, repeated by Ministry of Health Circular N. 12302 of 8/4/2020"3.

From this study on man, that is, on the bodies of the deceased, a possible truth emerges: what was 
diagnosed, both clinically and on radiographic imaging, as 'interstitial pneumonia' displays a series of thrombotic phenomena and alveolar damage: facts of clear fundamental importance for the therapy, as well as for patients' lives. This observation is sufficient to explain the importance of the anatomopathological study and research. A further autoptic study documents the formation of a syncytium starting with pneumocytes ${ }^{4}$.

It is to be noted that this type of research regards all sectors of medicine, not only one. It regards diagnosis, prognosis, therapy, prevention, etc. In the 1960s anatomopathological research brought about the identification of "hyaline membrane disease", as the cause of the death of an infant son of J.F. Kennedy.

So, after Virchow, society changes radically. The pharmaceutical industry develops. It does not have hospitals and exam rooms, but has laboratories and a great need to experiment. Experiments on man are substituted by those on other species. However, anatomopathoogy is always necessary in all fields: from prevention to medico-legal investigations, from early diagnosis to post-mortem exams. A diagnosis is not made if not supported by a histoor cyto-pathological exam. Cytology appears, fine-needle aspiration, intraoperatory diagnosis, genetic diagnosis, immuno-histo-chemistry, forensic medicine, cell cultures all appear. There is not polyp formation, or papilloma or ulceration, that is not qualified or graduated, classified or simply diagnosed, without a histological exam. Learning, on the part of students or specializing doctors today is almost completely digital (carrying out radiological, NMR and CAT exams and so on, on cadavers, it is possible to create three-dimensional virtual copies, on which it is possible to undertake anatomic, anatomopathological, or surgical investigations). However, those who have only gained this virtual experience would certainly find themselves in difficulty if they had to carry out a real autopsy. There is nothing like direct experience on man. For example, the consistency of a cirrhotic liver under incision.

Besides, new surgical techniques are developed, no longer in open surgery. These require a particular knowledge of the normal and the pathological anatomy. Microsurgery is a perfect example. During training, specializing students cannot always get experience on man. Also considering that there is no hemorrhaging in cadavers, therefore there is less difficulty, learning on man is always better. Microsurgical experience on man is often substituted by experience on animals. However, there are systems available for the simulation of surgical interventions on inert materials that faithfully reproduce the intraoperational scenario. Therefore, the need for bodies exists, or rather, it is increasing.

Public opinion is favourable to research, to science in the generic form; current morals are favourable, but the conditions are different, fortunately having changed for the better. There is no longer the relatively free availability of bodies as in the 19th century. Their provenance from among the poorer classes is no longer acceptable.

In this situation Law $\mathrm{n}^{\circ}$. 10 of 10.02 .2020 has been passed: "Norms on the subject of the post-mortem availability of ones' own body and of its tissues for the purposes of study, training and research", published in the Gazzetta Ufficiale: of 4.03.2020 $0^{5}$. The approval of the law is proof that the Government and Parliament are aware of the importance of research on man. The merit for its approval goes to all those who contributed to the project, presented by Professor Susanna Penco of the University of Genova, but also supported by th e Professor of Bioethics from the same university, Luisella Battaglia, who obtained a favourable opinion from the National Committee on Bioethics. The law provides for the voluntary donation of the body for the purposes of research as done, some three centuries or so ago, by the English philosopher Jeremy Bentham. This law can be made of common application, using the principles already valid for the post-mortem donation of organs.

However, there are some psychological and practical obstacles.

There must not be a document contrary to the donation. There must be a structure in place that can receive and keep the bodies and restore them to families at the end of examination. There must be a mentality, among teachers and researchers, the appreciates the opportunity offered by this new availability of corpses for experimentation. Everything must occur without expenses for the donors. Therefore, an organization must be foreseen. The costs would not be enormous, compared to the benefits. The universities already have structures and at least part of the personnel. The institutes of anatomopathology in faculties of medicine and surgery would be the natural site. As well as in the areas just mentioned, the advantages could also be noteworthy, especially in sectors of rare diseases and degenerative diseases of the CNS. In many of these sectors, there is a shortage of studies on man, because of the shortage of bodies. Last of all, these types of studies cannot fully replace experimentation on animals, but they can reduce it considerably. Therefore, it is in agreement with the programme of the three Rs (Reduce, Refine, Replace). No one should have any reason to oppose it.

\section{Conclusions}

As the importance, or rather, the inevitability of research on man, is indisputable, we now need to give it some concreteness, to implement what is the logical consequence of what has been outlined, as foreseen in the approved law. It is necessary to set out the path for its application and operation in the Italian universities, so as to 
give researchers the chance of making significant steps for progress in the areas of medicine and biology.

\section{Acknowledgements/}

Many warm thanks to Pier Paolo Cirillo (the president of Animal-Aid) for his precious advice.

\section{Donazione del corpo post mortem e note di storia della dissezione}

La storia della medicina, inizialmente confusa con pratiche religiose o magiche, mostra chiaramente con quanta difficoltà siamo arrivati allo spettacolare progresso scientifico attuale, partendo da superstizioni, pregiudizi, assurdità di ogni genere. Mi sembra ovvio sottolineare il fatto che sia stato necessario un enorme lavoro di ricerca specie-specifica, iniziando dalla struttura, cioè dall' anatomia. Si può sapere come è fatto, come funziona e come si ammala l'uomo, solo studiando l'uomo.

Uno dei primissimi chirurghi di cui si ha notizia è l'egiziano Imhotep. Certo uno dei primi conoscitori di anatomia e patologia umana.

In Europa, i greci avevano capito l'importanza dell'uomo, anche se in modo totalmente indifferente all'aspetto etico. Erofilo, tre secoli prima di Cristo, scopre la "Torcolare" scalpellando il cranio di uno schiavo vivo. Erasistrato, sempre sull'uomo, distingue circolo venoso e arterioso. Galeno, al contrario di Erofilo ed Erasistrato, compie esperimenti su altri animali, anche se non li ritiene affidabili come quelli sull'uomo. Tuttavia descrive la funzione degli organi e l'anatomia.

Col successo del cristianesimo e le invasioni barbariche, la ricerca su cadaveri scompare e si ha anche l'arresto del progresso nella medicina. Si ritengono fondate idee risalenti a Ippocrate (Dottrina degli umori), in realtà primo tentativo di spiegazione non magica o superstiziosa delle malattie. Alcune metodiche vengono praticate anche quando dannose.

La ripresa, il progresso scientifico ripartono nuovamente con la ricerca sull'uomo, che è attuata, talvolta, con grave pericolo per i ricercatori stessi, perchè possono essere accusati di stregoneria. Più tardi questo non accadrà più.

Il progresso, dunque, non si arresta totalmente, anche nel medio evo. Dal XII secolo lo studio dell'anatomia riprende sull'uomo; Fracastoro scopre il "contagio"; sorgono i primi ospedali. La ricerca su cadaveri non viene mai abbandonata del tutto, ma gli studi di medicina sono ancora uniti ad altro: ci si laurea in Medicina e Filosofia.

Medicina e chirurgia, però, procedono separatamente: il gran numero di feriti in battaglia favorisce la chirurgia. Lentamente si afferma il concetto di studi sull'uomo; Vesalio, dissezionando cadaveri, cambia l'anatomia, che risaliva agli studi di Galeno, ma anche i progressi in altre discipline sono importanti per il progresso medico.

Un'importantissima svolta avviene con i primi microscopi e le ricerche anatomiche, istologiche, anatomopatologiche di Malpighi e quelle di Harvey. Tuttavia, nel 1600, scoppia la peste a Milano e l'ignoranza è sovrana. La conoscenza scientifica è limitata a poche persone.

La vera svolta epocale, il salto nella modernità, avviene nel diciannovesimo secolo con Virchow. Questo anatomo-patologo è certamente uno dei padri della medicina moderna. (Non si possono citare tutti, ma non si possono tacere Kock, Pasteur e sarebbe ingeneroso non citare Semmelweis). Virchow rappresenta una svolta fondamentale perchè pone sistematicamente in relazione le alterazioni macro- e micro-scopiche trovate nell'esame autoptico con la sintomatologia rilevata prima della morte. Fa questo non in alcuni casi, ma sempre, sistematicamente. Dunque non spiega un caso, ma identifica un metodo che consente di spiegare i sintomi della polmonite, con "l'epatizzazzione del tessuto polmonare"; consente di mettere in relazione la cirrosi epatica con l'ittero e l'ascite, ecc ecc.

Virchow non è solo: la scoperta del "Micobacterium Tubercolosis", coltivato nella camera anteriore dell'occhio di bue, è anch'essa una scoperta di metodo e la stessa cosa sono le ricerche di Pasteur.

Non essendo più proibito l'uso di cadaveri a scopo di ricerca ed essendosi ormai affermata una nuova etica, impensabile in età ellenistica o romana, i corpi dei deceduti, non reclamati da alcuno, diventano mezzi di studio. Servono in tutti i campi: conoscere l'anatomia; sperimentare la fattibilità concreta di interventi chirurgici resi possibili da anestesia e antibiotici; esercitare l'abilità di futuri chirurghi; effettuare studi ed esercitazioni da parte degli studenti.

La Chirurgia, praticata in tutta l'antichità, ma concretamente limitata alla cura delle ferite, delle distorsioni, lussazioni, fratture, e non molto altro, ha uno sviluppo impressionante.

Le descrizioni dei primi interventi di gastrectomia, cistectomia o anche di semplice mastectomia, oggi intervento elementare, sono drammatiche. Inoltre gli 
interventi sono eseguiti senza, o con preparazione approssimativa. Esistono le relazioni di interventi tentati per la prima volta in epoca preantibiotica e prima dell' anestesia. Molto si deve alle esperienze compiute sui cadaveri. Come esempio si può citare l'adenomectomia prostatica, per via sovrapubica, che non sarebbe possibile apprendere, sperimentandola sul cane, a causa della maggiore altezza del pube. Il primo intervento riuscito sulla prostata, infatti, avviene per via perineale, nel XVII secolo. Non sappiamo se seguirono, com'è probabile, incontinenza ed impotenza.

Come allievo di un famoso chirurgo, avendo visto operare molti altri, posso dire che non pochi interventi, o varianti, sono stati ideati direttamente sul paziente ammalato. Altre volte c'è stata una lunga preparazione su cadaveri. Ancora una volta, però, non era rispettata l'etica: i cadaveri oggetto di studio erano quelli non reclamati da alcuno: solo $i$ corpi di poveri, il che è immorale. Ma siamo ormai arrivati ad un'epoca in cui la società e la ricerca evolvono rapidamente. Cambiano gli stessi corsi di studi. Discipline prima monolitiche si frammentano; altre ancora nascono od assumono nuova importanza. C'è necessità di nuove conoscenze in campi prima inesistenti (anestesia, microbiologia, statistica, etc.).

Gli studi di medicina richiedono minore esperienza diretta, su corpi umani, mentre aumenta contemporaneamente la necessità di ricerca nei nuovi settori: dei trapianti, della microchirurgia, dell'endoscopia, ecc.

Evidentemente gli insegnamenti di Virchow sono tuttora attuali.

Sono però comparse malattie nuove, mentre altre sono divenute meno frequenti, oppure hanno assunto caratteristiche diverse.

\section{Epoca attuale}

La pandemia da Corona Virus è un esempio eclatante dell'importanza della ricerca anatomopatologica.

Vengono effettuate ricerche in Cina, (Gennaio e Febbraio 2020; 3 autopsie). Poi, dal 22 Marzo 2020, nell'Ospedale Giovanni XXIII a Bergamo (Carsana L. et al. $^{1}$ e nell'Ospedale Luigi Sacco, in Milano(38 autopsie). Queste indagini riferiscono un fatto fondamentale per la comprensione, la terapia, la prognosi. Vengono infatti trovati i primi reperti disseminati di tromboembolia e di danno alveolare diffuso. Le autopsie sono state eseguite nonostante il parere del Ministero che forniva istruzioni molto restrittive sulla loro esecuzione. "La posizione del Ministero è espressa nel rapporto ISS Covid-19 n.6 del 23/3/2020 (Nuova versione il 26/3/2020) ${ }^{2}$ e, quindi, ribadita dalla Circolare del Ministero della Salute N. 12302 del $8 / 4 / 2020 " 3$.
Da questo studio diretto sull' uomo, cioè sui corpi dei deceduti, emerge invece una possibile verità: quella che, sia clinicamente, sia alle immagini radiologiche, era stata diagnosticata come "polmonite interstiziale" mostra una serie di fenomeni trombotici e danni alveolari. Fatti evidentemente di fondamentale importanza per la terapia, nonché per la vita dei pazienti. Quest'osservazione è sufficiente per far capire l'importanza dello studio e della ricerca anatomo-patologica. Un ulteriore studio autoptico documenta la formazione di un sincizio a partenza dagli pneumociti ${ }^{4}$.

$\mathrm{Si}$ fa notare che questo tipo di ricerche riguarda tutti i settori della medicina, non uno solo. Riguarda la diagnosi, la prognosi, la terapia, la prevenzione, etc. Negli anni '60 del secolo scorso, la ricerca anatomopatologica portò all'identificazione della "malattia da membrane ialine", come causa della morte di un figlio del presidente J. F. Kennedy.

Dunque la società, dopo Virchow è cambiata radicalmente. E' nata l'industria farmaceutica, che non ha ospedali e sale settorie, ma ha laboratori e una grande necessità di sperimentare. La sperimentazione sull' uomo viene sostituita da quella su altre specie. Tuttavia l'anatomia patologica è sempre più necessaria in tutti i campi: dalla prevenzione alle indagini medico-legali, dalla diagnosi precoce a quella post mortem. Non si fa una diagnosi che non sia suffragata dall'esame isto- o cito-patologico. Compare la citologia, l'agoaspirato, la diagnosi intraoperatoria, la diagnosi genetica, l'immunoisto-chimica, la medicina forense, le colture cellulari. Non c'è formazione poliposa, o papilloma, o ulcerazione, che non sia qualificata, graduata, classificata o semplicemente diagnosticata, senza esame istologico. L'apprendimento da parte di studenti o specializzandi oggi è quasi totalmente digitale (eseguiti esami radiologoci, RMN, TAC, ecc., su cadaveri, è possibile crearne copie virtuali tridimensionali, su cui si possono eseguire indagini anatomiche, anatomopatologiche, o chirurgiche). Tuttavia, coloro che hanno acquisito questa sola esperienza virtuale, si troverebbero certo in imbarazzo, se dovessero effettuare un'autopsia reale. Nulla può eguagliare l'esperienza diretta sull'uomo. Per es. quella della consistenza, al taglio, di un fegato cirrotico.

Si sviluppano inoltre nuove tecniche chirurgiche, non più a cielo aperto, che richiedono una particolare conoscenza dell'anatomia normale e patologica. La microchirurgia è un esempio perfetto. Non sempre, durante l'apprendimento della tecnica, gli specializzandi possono fare esperienza sull'uomo. Anche considerando che nel cadavere non c'è emorragia, dunque c'è minore difficoltà, l'apprendimento sull'uomo è sempre migliore. L'esperienza microchirurgica sull'uomo è spesso sostituita dall'esperienza sull'animale. Sono comunque disponibili sistemi per la simulazione di interventi chirurgici su 
materiali inerti che riproducono fedelmente lo scenario intraoperatorio. Il bisogno di corpi dunque, esiste, anzi, è aumentato.

L'opinione pubblica è favorevole alla ricerca, alla scienza in senso generico; la morale corrente è favorevole, ma le condizioni sono diverse, fortunatamente cambiate in meglio. Non c'è più la relativa disponibilità di corpi del secolo diciannovesimo. La stessa provenienza dalla classi più povere, non è più accettabile.

In questa situazione è stata approvata la legge $n$. 10. del 10/02/2020: "Norme in materia di disposizione del proprio corpo e dei tessuti post-mortem a fini di studio, formazione e ricerca", pubblicata nella G.U. del 4/3/2020 5 . L'approvazione della legge è la prova che Governo e Parlamento sono consapevoli dell' importanza della ricerca sull'uomo. Il merito dell'approvazione va a tutti coloro che hanno contribuito al progetto, presentato dalla prof.ssa Susanna Penco, dell'Università di Genova, ma sostenuto anche dalla prof.ssa di Bioetica della stessa università, Luisella Battaglia, che ha ottenuto un pronunciamento favorevole del Comitato Nazionale di Bioetica. La legge prevede la donazione volontaria del corpo, a scopo di studio e ricerca come già fece, tre secoli or sono, il filosofo inglese Jeremy Bentham. Questa legge può essere resa di comune applicazione, con i principi già validi per la donazione di organi post-mortem.

Esistono però alcuni ostacoli psicologici e pratici.

Non deve esistere un documento contrario alla donazione. Deve esistere una struttura che possa ritirare, conservare i corpi e restituirli alle famiglie a esami

\section{References}

1) Carsana L Sonzogni A, Nasr A, Rossi RS, Pellegrinelli A, Zerbi P. et al., Pulmonary post-mortem findings in a series of COVID-19 cases from northern Italy: a two-centre descriptive study. The Lancet Infectious diseases (internet). ElsevierBV2020 Oct;20(10):1135-40. DOI: 10.1016/S1473-3099(20)30434-5

2) Gruppo di Lavoro ISS Cause di morte Covid-19.Istituto superiore Di sanità(ISS)- Procedura per l'esecuzione di riscontri diagnostici in pazienti deceduti con infezione da SARS-COV- 2. Rapporto ISS COVID-19 n 6_2020 del23/3/2020 aggiornato poi il $23 / 3 / 2020$ 173. Legge $n 10$, del10,02,2020 Norme in materia di disposizione del proprio corpo e dei tessuti post-mortem a fini di studio, formazione e ricerca scientifica. GU 4.3.2020 conclusi. Deve esistere una mentalità dei docenti e ricercatori che veda l'opportunità offerta da questa nuova disponibilità di corpi per sperimentazione. Tutto deve svolgersi senza spese per i donatori. Dunque, deve essere prevista un' organizzazione. Le spese non sarebbero grandi, rispetto ai possibili benefici. Le università possiedono già le strutture ed almeno parte del personale. Gli istituti di Anatomia Patologica delle Facoltà di Medicina e Chirurgia sarebbero le sedi naturali. Oltre che nelle aree già elencate, i vantaggi potrebbero essere notevoli, specialmente nei settori delle malattie rare e delle malattie degenerative del SNC. In molti di questi settori esiste un carenza di studi sull'uomo, per mancanza di corpi. Infine, questo tipo di studi non potrà sostituire totalmente la sperimentazione su animali, ma la ridurrà. Dunque è in sintonia con il programma delle tre $\mathrm{R}$ (Reduce, Refine, Replace). Nessuno dovrebbe aver motivo di opporsi.

\section{Conclusioni}

Essendo indiscutibile l'importanza, anzi l'inevitabilità della ricerca sull'uomo, si tratta ora di dare concretezza, di realizzare quanto è conseguenza logica di ciò che è stato esposto, come prevede la stessa legge approvata. E' necessario avviare il percorso di applicazione e operatività nelle università italiane, per dare la possibilità ai ricercatori di compiere un significativo passo avanti nell' area della medicina e della biologia.

\section{Ringraziamenti}

Si ringrazia vivamente Pier Paolo Cirillo (presidente AnimalAid) per i preziosi consigli.

3) Circolare Ministero Della Salute n. 12302 del 08,04,2020. Indicazioni Emergenziali Connesse all'Epidemia da COVID-19 riguardanti il settore funebre, cimiteriale $\mathrm{e}$ di cremazione. Available at the address: https//www.trovanome.salute.gov.it/norme/ renderNormsaanPdf. anno2020\&codLeg-738328

4) Bussani R, Schneider E, Zentilin L, Collesi C, Ali H, Braga L, et al. Persistence of viral RNA, pneumocyte syncytia and thrombosis are hallmarks of advanced COVID-19 pathology. EBioMedicine [Internet]. Elsevier BV; 2020 Nov;61:103104. DOI: 10.1016/j.ebiom.2020.103104

5) Legge n. 10, del 10.02.2020 Norme in materia di disposizione del proprio corpo e dei tessuti post-mortem a fini di studio, formazione e ricerca scientifica. GU 4.3.2020. 